\title{
Alzheimer's Disease and Animal Models in Retrospect
}

\section{James Oluwagbamigbe Fajemiroye*}

Laboratório de Farmacologia de Produtos Naturais, Departamento de Ciências Fisiológicas, Instituto de Ciências Biológicas, Universidade Federal de Goiás, Brazil

\begin{abstract}
Alzheimer's disease (AD) is one of the neurodegenerative diseases that affect millions of people worldwide. $A D$ could rob patients of their ability to recall, reason and carry out executive functions. Pathophysiological studies of $A D$ have revealed the gradual loss of neurons, function and ultimate death of neurons (apoptosis). Mutations, oxidative stress, excitotoxicity, infectious diseases are among the principal causes of neuronal degeneration. Despite the prescription of a wide range of drugs to treat $A D$, the emergence of effective treatments to halt the progress or reverse this disease has remained elusive for years. Series of preclinical studies have been developed to ensure better understanding of the neurobiology of $A D$ and engender the discovery of new drugs. This review provides an overview on the pathophysiology, pharmacotherapy and preclinical models of AD in an attempt to bring together current research efforts, challenges, achievements and prospect for the discovery of drugs to treat AD. Pathophysiological evidences of this neurodegenerative disease has shown the involvement of multiple neural mechanisms. So far, the research approaches and treatment of this disease still remain largely unsatisfactory. However, there are possibilities of surmounting current challenges with new technology, diagnostic criteria and translational approach that effectively reflect clinical etiology of $A D$ in experimental animals.
\end{abstract}

Keywords: Neurodegenerative disease; Alzheimer's disease; Pathophysiology; Pharmacotherapy; Preclinical models

\begin{abstract}
Abbreviations: AD: Alzheimer's Disease; APP: Amyloid Precursor Protein; NMDA: N-methyl-D-aspartate; ATP: Adenosine Triphosphate; Ab: Amyloid Beta, $\mathrm{H}_{2} \mathrm{O}_{2}$ : Hydrogen Peroxide; NO: Nitric Oxide; Ach: Acetylcholine; $A \beta$ : $\beta$-amyloid; NGF: Nerve Growth Factor; PPAR $\gamma$ : Peroxisome Proliferator-Activated Receptor Gamma; HMGCoA: 3-hydroxy-3-methylglutaryl-coenzyme A; GABA: GammaAminobutyric Acid; CT: Computed Tomography; MI: Multiphoton Imaging; PET: Positron Emission Tomography; MRI: Magnetic Resonance Imaging; FDG-PET: Flouro-2-deoxy-D-glucose-positron emission tomography
\end{abstract}

\section{Oxidative Stress and Neurodegeneration}

The daily activities for human survival often constitute serious challenges and threats to human health [1]. Stressful life events that are accompanied with psychological and behavioral reactions are believed to predispose people to mental illness [2,3]. Intense oxygen release could predispose human to stress induced neurodegenerative diseases. Oxygen is a critical element for all living cells or neuron [4]. This essential element is involved in oxidative phosphorylation to generate adenosine triphosphate (ATP), a vital metabolic process to neuronal maintenance and survival $[5,6]$.

However, excessive release of oxygen and subsequent oxidative stress have been attributed to the failure of the complex regulatory systems and disruption of cellular homeostatic processes. Oxidative stress could be associated to the imbalance in the equilibrium between oxidant and antioxidant molecules [7]. Predominant activities of prooxidant molecules could lead to a chain of effects that promote further generation of reactive oxygen species (ROS) and free radicals. These molecules are potentially neurotoxic. The high levels of oxidative stress can cause necrosis, ATP depletion and prevent the occurrence of controlled apoptotic death [8].

For normal functioning, the brain requires a high supply of oxygen and glucose to enable continuous generation of ATP pool. Hence, the brain is more susceptible to oxygen overload and free radical generation [9]. 1-2\% of $\mathrm{O}_{2}$ consumed is converted to ROS in a normal condition but in an aged brain or in an oxidative stress induced pathological condition, this percentage could increase dramatically due to a reduction in the level of antioxidants and low regenerative capacity of aged brain [9].

Meanwhile, oxidative stress and free radical generation play pivotal role in redox reactions that result into $\mathrm{AD}$ [7]. An age-related memory impairments correlate with a reduction in brain and plasma antioxidants $[10,11]$. ROS such as hydrogen peroxide $\left(\mathrm{H}_{2} \mathrm{O}_{2}\right)$, nitric oxide $(\mathrm{NO})$, superoxide anions and the highly reactive hydroxyl and monoxide radicals $(\mathrm{OH} \cdot \mathrm{NO} \cdot)$ are among the free radicals that constitute high risk to neuronal loss or damage [12-15]. Excessive oxidative activities in $\mathrm{AD}$ are characterized by high levels of oxidised proteins, formation of toxic species like peroxides, alcohols, aldehydes, free carbonyles, ketones, cholestenone advanced glycation end products, lipid peroxidation end products and oxidative modifications in nuclear and mitochondrial DNA [16-26]. Epidemiological evidences have shown that inflammation, stroke, hypertension, diabetes, smoking, head trauma, depression, infection, tumors, vitamin deficiencies, chemical exposure, endocrine, immune and metabolic dysfunctions constitute risk factors of neurodegenerative diseases [27,28].

In this minireview, we attempt to summarize the prevalenceof $\mathrm{AD}$, current understanding of pathophysiology, treatment and preclinical research strategies of $\mathrm{AD}$. We review some of the biomarker that has been targeted by drugs to mitigate degeneration of neurons. It is beyond the scope of this paper to provide full review of the broad range of hypothesis or the enormous outpouring of scientific data on AD.

\section{Brief Facts about Alzheimer's Disease and its Prevalence}

Alzheimer's disease $(\mathrm{AD})$ is a chronic progressive disease

*Corresponding author: James Oluwagbamigbe Fajemiroye, Laboratório de Farmacologia de Produtos Naturais, Departamento de Ciências Fisiológicas Instituto de Ciências Biológicas, Universidade Federal de Goiás, Brazil, CP 131, CEP 74001-970, Goiânia, GO, Brazil, Tel: (62) 35211491; Fax: (62) 35211204 E-mail: olulolo@yahoo.com

Received August 13, 2014; Accepted September 28, 2014; Published September 30,2014

Citation: Fajemiroye JO (2014) Alzheimer's Disease and Animal Models in Retrospect. Med chem 4: 701-703. doi:10.4172/2161-0444.1000215

Copyright: ( 2014 Fajemiroye JO. This is an open-access article distributed under the terms of the Creative Commons Attribution License, which permits unrestricted use, distribution, and reproduction in any medium, provided the original author and source are credited. 
characterized by memory loss and deficits in different cognitive domains like aphasia, agnosia, apraxia, or executive function $[29,30]$. These deficits could interfere with daily life or work. It is estimated that approximately 5.4 million Americans are currently diagnosed with $\mathrm{AD}$ [31]. The risk of being affected by $\mathrm{AD}$ increases dramatically with age. This disease cost the U.S. economy billions of dollars each year in direct health care costs and loss of opportunities [32] in addition to immense emotional burden on patients and society. Globally, $\mathrm{AD}$ is estimated to cost $\$ 604$ billion in 2010 alone, a value which is expected to increase as cases of this disease (currently estimated at 36 million) triple by 2050 [33].

The prevalence rate of $\mathrm{AD}$ is about $7 \%$ within the age group of 65 years and above $[34,35]$. Nearly one-half of Americans 85 years and older have AD [31]. By 2050 it has been estimated that the headcount of people above 80 years old will approach 370 million worldwide out of which $50 \%$ of those that are older than 85 years will suffer Alzheimer's disease [36]. This dementia is a complex neurodegenerative disease caused by multiple genetic and environmental factors [37]. The understanding of the underlining pathophysiology of this neurodegenerative disease could lead to the postulation of hypothesis, development and validation of animal models. An effective animal model could promote preclinical screening of drugs prior to clinical trials and perhaps drug approval (Figure 1).

\section{Pathophysiology of Alzheimer's Disease}

For the fact that cognitive failure at the clinical onset of $\mathrm{AD}$ is a process that has progressed silently for many years [38], the pathophysiological processes may have evolved for years prior to diagnosis. Pathophysiological informations have continue to associate the causes of $\mathrm{AD}$ to the complex interactions among multiple genetic, epigenetic, and environmental factors. Both anatomical and functional alterations have been revealed in patients and individual that are at risk of developing $\mathrm{AD}$. Morphometric measurements from postmortem tissues to live patients [39] by using radiological imaging techniques have advanced the understanding of pathophysiology of $\mathrm{AD}$. In $\mathrm{AD}$, progressive decreases in cortical thickness that correlate with cognitive decline can be detected by magnetic resonance imaging [40,41]. The electrophysiological and biochemical data on transgenic mouse models $[42,43]$ suggest that $\mathrm{AD}$ could also be associated with aberrant network activity that could actively interfere with the biological processes underlying cognitive functions in addition to the silencing of neurons. Cognitive decline in $\mathrm{AD}$ correlates to loss of synapses and dendritic spines than loss of neurons [44].

The characteristic pathological features of $\mathrm{AD}$ include the loss of cholinergic function as a result of a decrease in synaptic levels of acetylcholine $(\mathrm{ACh})$, increase in stress induced oxidation, $\beta$-amyloid

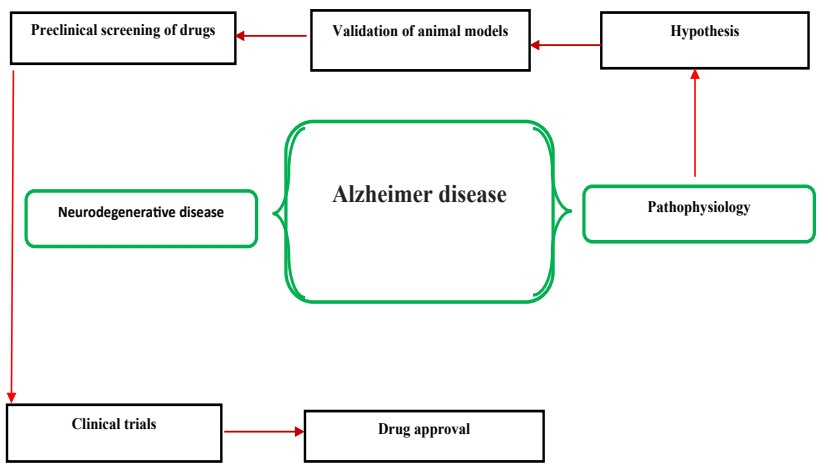

Figure 1: Graphical representation of some steps leading to the development of drugs for the treatment of Alzheimer's disease. cascade (accumulation of amyloid cerebral plaques of abnormal proteins deposited outside neurons and neurofibrillary tangles of abnormally insoluble tau - filaments of protein that has been hyperphosphorylated inside neurons in affected brain regions) [30], steroid hormone deficiencies, depletion of other neurotransmitters, excitotoxicity caused by excessive glutamate release, loss of neural synapses, dietary factors (fatty diet, alcohol etc), mitochondrial dysfunction, inflammation, ischemia, insulin signaling, and cholesterol metabolism [45]. Despite closer correlation of NFTs with cognitive decline in $\mathrm{AD}$ than plaques [46], preclinical study with transgenic mice indicate that the microtubule-associated protein tau, the main constituent of NFTs, can cause neuronal dysfunction independently [47]. Pathophysiological information on AD provides critical means of improving our understanding of the underlining causes of $\mathrm{AD}$ and develop new approaches for treatment and prevention.

\section{Treatment Strategies and Pharmacotherapy}

The treatment strategies for $\mathrm{AD}$ include the use of $\mathrm{A} \beta$ aggregation inhibitors, antioxidants, $\gamma$-secretase modulators, NGF mimics, PPAR $\gamma$ agonists, HMG-CoA reductase inhibitors (statins), ampakines, calcium channel blockers, GABA receptor antagonists, $\gamma$-Secretase inhibitors, glycogen synthase kinase inhibitors, muscarinic receptor agonists, cholinesterase inhibitors, nicotinic receptor modulators, phosphodiesterase inhibitors, serotonin receptor antagonists, NGF gene therapy, non-steroidal anti-inflammatory drugs, hormone replacement therapy $[48,49]$. Based on these strategies, different classes of drugs have been developed and approved for the treatment of $\mathrm{AD}$. One of the drugs that are currently approved by the FDA for the treatment of $\mathrm{AD}$ inhibit acetylcholine esterase. Cholinergic therapy remains one of the best- developed therapy that is being used totreat mild to moderate $\mathrm{AD}$ [50]. The loss of cholinergic function which has been associated to memory impairment can be restored with acetylcholinesterase inhibitors like tacrine donepezil, galantamine, rivastigmine, physiostigmine [48].

Tacrine is a non-competitive, irreversible inhibitor of both acetyl and butyryl cholinesterase. In the United States, tacrine was the first anticholinesterase to be approved for the symptomatic treatment of $\mathrm{AD}[51,52]$. However, the high cases of hepatotoxicity and limited efficacy of tacrine have led to the restriction of its clinical application. Rivastigmine is a pseudo-irreversible inhibitor of both acetyl and butyryl cholinesterases with relatively short half-life [53]. In addition to synthetic compounds, some secondary metabolites that are isolated from plants have demonstrated good inhibition of cholinesterases. An alkaloid like galantamine is a reversible inhibitor of acetylcholinesterase. However, clinical application of these alkaloids has been reported to cause some gastrointestinal disorders [54]. Physostigmine is another alkaloid that has shown some therapeutic efficacy with high occurrence of nausea and vomiting [55]. Other anticholinesterases in development include metrifonate an organophosphorus that inhibits activities of acetylcholinesterase irreversibly [8]. The cases of muscle weakness and potential neurotoxicity have generated concerns and delayed further development [56].

The approval of drugs that could antagonize NMDA-type glutamate receptors to prevent aberrant neuronal stimulation [57] has raised the hope of an effective treatment of $\mathrm{AD}$. Being the major excitatory neurotransmitter in the brain, glutamate could interact with both ionotropic and metabotropic glutamate receptor - the N-methyl$\mathrm{D}$-aspartate (NMDA) as an agonist to mediate neuroplasticity and memory formation. Meanwhile, excessive activation of the NMDA receptors by glutamate has been associated to characteristic neuronal degeneration in $\mathrm{AD}$ [58]. NMDA antagonists have been shown to 
attenuate glutamate induced neurotoxicity [59]. An NMDA receptor antagonist such as memantine, attenuates cognitive deficits in patients with mild $\mathrm{AD}[60]$. However, this drug do not retard the processes of neuritic dystrophy, thereby limiting their clinical efficacy [61].

In addition, some of the neuroprotective drugs like arovastatin, ginko biloba, simvastatin, tarenflurbil, rosiglitazone, tramiprosate, xaliproden, valproate, docosahexanoic, solanezumab, semagacestat, dimebon bapineuzumab etc being used in the treatment of AD exhibit varying degree of efficacy. A mediterranean diet which is characterized by a low- to-moderate intake of saturated fatty acids, moderately high intake of fish, low-to-moderate intake of dairy products, low intake of meat and poultry, and a moderate amount of alcohol has been demonstrated to be associated with lower risk of $\mathrm{AD}$ [62]. The diet with component like epigallocatechin-3-gallate enriched with omega-3 polyunsaturated fatty acids have been reported to reduce $A \beta$ generation in Tg2576 mice [63,64]. The chelation of metals like Zinc and Copper with cliquinol could reduce the concentration of heavy metals in the brain and consequently inhibit $\mathrm{Ab}$ aggregation and deposition of senile plaques [65].

The $5 \mathrm{HT}_{3} \mathrm{~A}$ receptor antagonists like DAU 6215, granisetron, ondansetron, RS-56812, SEC 579 and WAY 100579 have putative procognitive effects given their ability to potentiate the release of ACh and enhance cognitive function. Also in animal models, a number of biomarkers of AD have been effectively targeted. Vaccination targeting $\mathrm{A} \beta$ in mice has shown promising results. Vaccination of young PDAPP mice with the $A \beta 42$ peptide inhibits the formation of neuritic $A \beta$ plaques and reduces this biomarker in older mice [66]. Amyloid beta peptide immunization has improved cognitive impairments and reduced the formation of plaques [67]. In amyloid-forming PDAPP mice, both active and passive immunization $[66,68]$ have shown reduction in amyloid beta, neuritic and inflammatory related pathology. Further studies have shown that immunization of amyloid forming presenilin/ APP or TgCRND-8 mice $[69,70]$ could reverse age/amyloid-related cognitive decline. Although there are hopes that these results will translate into better understanding of $\mathrm{AD}$ and drug design, it is still early to assess whether the results from mice are reliable predictors of efficacy in humans [71].

Some of the promising therapeutic mechanisms of drugs against $\mathrm{AD}$ that were proposed in the previous work include protective effect, antioxidant properties and potentiation of APP processing [72-75]. Based on the evidences of oxidative damage as well as inflammation and mitochondrial impairments in $\mathrm{AD}[76,78]$, series of attempts have been made to retard disease progression with antioxidants $[79,80]$, anti-inflammatory drugs [81], or putative mitochondrial protectors [76]. In this regards, clinical data on the application of vitamin $\mathrm{E}$ has shown some promising results [82] except for the occurrence of blood coagulation at therapeutic dose. Unfortunately, none of these interventions has produced effective therapeutics. The results so far implies that researchers are still faced with the herculean tasks of unraveling the physiopathology of this diseases, propose correct hypothesis, and execute experimental models that can be translated. A substantial revision of the diagnostic criteria for $\mathrm{AD}$ remains fundermental [83].

\section{Preclinical Models for Drug Discovery}

Non-human primate models like Drosophila melanogaster, Caenorhabditis elegans, rodents among others have offered means of understanding the biology of $\mathrm{AD}$ and pharmacological evaluation of novel compounds on biological targets that pareticipate in the pathogenesis of $\mathrm{AD}$. Unlike small animals, dogs and other primates
[84-86] have shown some compelling symptoms of neuropathology with aging.

Several works in the literature have involved the postulation and test of hypothesis through the use of aged rodents, pharmacologically and surgically induced memory impairment, transgenic and nontransgenic models. Some of the animal model of $\mathrm{AD}$ are target-driven so as to ensure face, construct and predictive validity. This approach could facilitate translation of therapeutic studies from animals to humans.

The clearance of plaques in both mice and humans in the amyloidbeta $(A \beta)$ immunotherapy trial of bapineuzumab $[87,88]$ and the biological activities of gamma-secretase inhibitors (semagacestat and BMS-708163) demonstrated good example of target (A $\beta$ levels)focused preclinical animal data $[89,90]$. The failure of some promising preclinical trials to produce desirable effects during clinical trials further reinforces the idea of our limitation in physiopathological understanding of $\mathrm{AD}$ and inadequacy of animal modelling of this disease.

Some of the key considerations for animal studies of $\mathrm{AD}$ as highlighted by Shineman [91] include; (a) clear delineation of study hypothesis, (b) identification of a specific measure to assess the primary and secondary outcomes, (c) study should target translatable biomarkers, (d) issues of sex, timing of treatment and age of animals should be considered, (d) specify inclusion and exclusion criteria, (e) evaluate bioavailability of drugs, (f) carefully design appropriate statistical analysis plan prior to commencement of study, (g) conduct power analysis and estimates of sample size prior to initiation of the study, (h) treatment groups should be randomized while employing blinding procedures for assessments, (i) report both positive and negative results, (j) report details of strain, housing, diet, dropout events and in-trial exclusions, $(\mathrm{k})$ report the flow of animals through the treatment plan. The principle of bench to bed requires reciprocal translation of in vitro, ex vivo and in vivo assays to clinical studies as shown in Figure 2.

Progress in radiological imaging techniques [39] has offered great opportunity for investigational and translational researches. The imaging techniques like Computed tomography (CT), multi-photon imaging (MI) magnetic resonance imaging (MRI), magnetic resonance spectroscopy, functional MRI, arterial spin labeling MRI, flouro-2deoxy-D-glucose-positron emission tomography, (FDG-PET), PET amyloid imaging, PET tau imaging, single-photon emission computed tomography/computed tomography among others and biochemical assays on biological fluids such as plasma and cerebrospinal fluid [9295] in rodents could permit the assessment of biomarkers (target)-drug

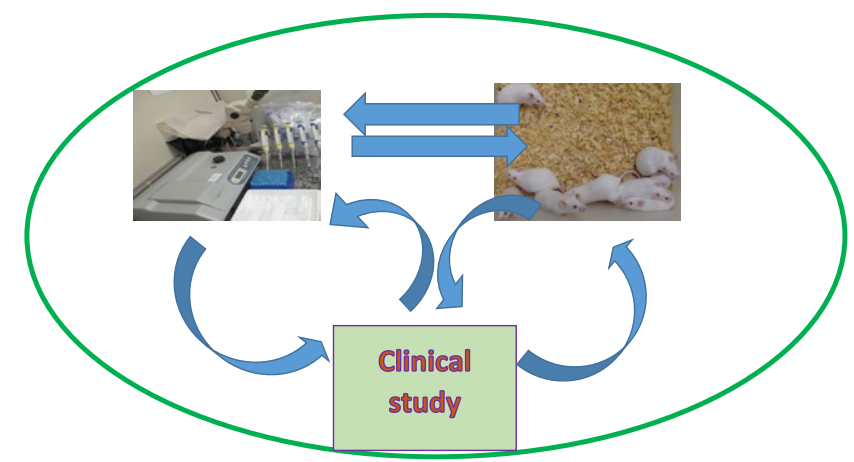

Figure 2: Showing hypothetical dynamics in the translation of in vitro, ex vivo, in vivo and clinical studies. 
interaction, real time monitoring of biological responses to treatment and translatability of a novel therapy in a clinical trial.

Imaging could facilitate visualization of $A \beta$ deposition in in vivo and monitoring the success of treatment [96]. Unlike MI which is compatible with human and mouse tissue, PET, CT, and MRI require a higher resolution in animals in order to capture their smaller brain structures. These imaging techniques allows for a non-invasive monitoring of pathological changes and to correlate these with behavioral changes [96]. The invention of a novel PET tracer that binds to $\mathrm{A} \beta$ plaques (11C-labelled Pittsburgh Compound-B) has attracted significant attention [97]. An age-dependent increase in this PET tracer in APP23 mice was found to consistently accompany an increase in the accumulation of $A \beta$ [98]. An age-dependent memory loss has been evaluated in Tg2576 in the Morris water maze. Spatial reference memory was demonstrated to decline progressively from 6 months of age [99].

In recent times, many of the new therapeutic strategies are based on findings with transgenic animal [100]. A reasonably good approximation of $\mathrm{AD}$ has been achieved through transgenic mice models [101]. The first transgenic mice employed cDNA-based or yeast artificial chromosome constructs to elicit expression of human APP gene, APP751, APP695, Ab and C-terminal fragments of APP [102-108].

In an elegant study of AD's biomarker using tau models of transgenic mice, it was demonstrated that suppression of P301L tau expression in $\mathrm{rTg} 4510$ tau transgenic mice, which normally express the mutant protein at a high level, reverses behavioral impairments in these mice [109]. A reduction in the activity of the $\beta$-secretase $\mathrm{BACE}$ by crossing APP transgenic mice onto a $\mathrm{BACE}^{-/-}$reduced $\mathrm{A} \beta$ formation and deposition [110]. In contrary, the overexpression of transgenic BACE increased $A \beta$ and plaque formation in APP/BACE Mice. BACE-deficiency also reversed the behavioral changes observed in several APP transgenic strains [110]. Gene's suppression has also been employed to anticipate the effects of new molecules designed to regulate proteins that are involved in the pathogenesis of $\mathrm{AD}$ [30]. The results on presenilin and $\beta$-secretase knockout mice have shown interesting results $[111,112]$.

In addition to secretase model, apoE [113-115], axonal transport models [116], studies in fruit flies-Drosophila melanogaster [117,118], studies in nematodes - Caenorhabditis elegans [119,120] among others have been used as animal models of AD. The application of transcriptomics and proteomics are increasingly being used in animal models of $\mathrm{AD}$ to identify novel genes and proteins that are regulated differentially [121].

Animal models have contributed immensely to the understanding of the underlying mechanisms of $\mathrm{AD}$. However, new treatments arising from the gain in pathogenic knowledge through animal models like knockout and transgenic mice are yet to engender remarkable improvement [48]. Athough there are number of interesting experimental strategies that are under investigation [42,43,122-125], for almost 10 years after the description of BACE as a potential target in Alzheimer's disease, there is no record of treatment or utility on the basis of this information [126,127]. Animal models are often limited in scope [128-131] as psychiatric diagnosis depends on the patient's verbal history of illness, reports of subjective feelings, and cognitive performance [132-139]. Animal models could not recapitulate and translate these clinical features effectively as animals rarely show disease mechanisms, symptoms or behavioral alterations that are equivalent to those in humans $[128,129]$. Despite the high expectation, very few of the findings in animal models have been validated in humans or successfully translated into disease-modifying therapies.

\section{Final Considerations}

The identification of different biomarkers, biological processes and possible mechanisms that are associated with all phases of AD prior to signs of functional deficits remain crucial. Since increasingly cognitive failure could correlate with series of qualitative and quantitative biological alterations, researchers could be better guided in their approach by considering all the temporal changes that take place prior to detectable clinical onset of $\mathrm{AD}$. Although there seems to be a better understanding of $\mathrm{AD}$ among scientists, it is still too early to tell whether these understandings have greatly improved diagnosis, drug development strategies and treatment of patients. However, with the advent of innovative preclinical approaches that optimize interpretation of results, there seems to be an array of hope for effective prevention and treatment of AD. On the basis of underlining hypothesis on pathophysiology of $\mathrm{AD}$, transgenic mice models have been a major breakthrough despite its limitations. Since, there are possibility of synergistic or signaling effects of biomarkers the current investigation of biomarkers in isolation may not be a holistic approach towards unravelling the entire mechanisms that are involved in the processes leading to AD. Investigative measures and drug development efforts should reflect the multifactorial attribute of this disease. Temporal measurement of neural function, identification of vulnerable neurons and effective use of imaging techniques could offer unique advantages for better understanding and improved treatment of $\mathrm{AD}$.

\section{References}

1. Lillberg K, Verkasalo PK, Kaprio J, Teppo L, Helenius H, et al. (2003) Stressful life events and risk of breast cancer in 10,808 women: a cohort study. Am J Epidemiol 157: 415-423.

2. Rahe RH (1979) Life change events and mental illness: an overview. J Human Stress 5: 2-10.

3. Kendler KS, Karkowski LM, Prescott CA (1999) Causal relationship between stressful life events and the onset of major depression. Am J Psychiatry 156: 837-841.

4. Stamati K, Mudera V, Cheema U (2011) Evolution of oxygen utilization in multicellular organisms and implications for cell signalling in tissue engineering. $\mathrm{J}$ Tissue Eng 2: 2041731411432365.

5. Catherine N, Miriam C, Clare H, David A (2012) Oxidative phosphorylation, not glycolysis, powers pre- and postsynaptic mechanisms underlying brain information processing. J Neurosci 32: 8940-8951.

6. Gnaiger E (2001) Bioenergetics at low oxygen: dependence of respiration and phosphorylation on oxygen and adenosine diphosphate supply. Respir Physiol 128: $277-297$.

7. Gella A, Durany N (2009) Oxidative stress in Alzheimer disease. Cell Adh Migr 3: 88-93.

8. Beal MF (2005) Mitochondria take center stage in aging and neurodegeneration Ann Neurol 58: 495-505

9. Lepoivre M, Flaman JM, BobÃ® P, Lemaire G, Henry Y (1994) Quenching of the tyrosyl free radical of ribonucleotide reductase by nitric oxide. Relationship to cytostasis induced in tumor cells by cytotoxic macrophages. J Biol Chem 269: 21891-21897.

10. Berr C (2000) Cognitive impairment and oxidative stress in the elderly: results of epidemiological studies. Biofactors 13: 205-209.

11. Perrig WJ, Perrig P, Stahelin HB (1997) The relation between antioxidants and memory performance in the old and very old. J Am Geriatr Soc 45: 718-724.

12. Cadet JL (1988) Free radical mechanisms in the central nervous system: an overview. Int J Neurosci 40: 13-18.

13. Richardson JS, Subbarao KV, Ang LC (1990) Biochemical indices of peroxidation in Alzheimer's and control brains. Trans Am Soc Neurochem 21:113. 
14. Youdim MB, Lavie L (1994) Selective MAO-A and B inhibitors, radical scavengers and nitric oxide synthase inhibitors in Parkinson's disease. Life Sci 55: 2077-2082

15. Yoshikawa T (1993) Free radicals and their scavengers in Parkinson's disease. Eur Neurol 33 Suppl 1: 60-68.

16. Hamilton ML, Van Remmen H, Drake JA, Yang H, Guo ZM, et al. (2001) Does oxidative damage to DNA increase with age? Proc Natl Acad Sci U S A 98: 10469-10474.

17. Mecocci P, Beal MF, Cecchetti R, Polidori MC, Cherubini A, et al. (1997) Mitochondrial membrane fluidity and oxidative damage to mitochondrial DNA in aged and AD human brain. Mol Chem Neuropathol 31: 53-64.

18. Bassett CN, Montine TJ (2003) Lipoproteins and lipid peroxidation in Alzheimer's disease. J Nutr Health Aging 7: 24-29.

19. Picklo MJ, Montine TJ, Amarnath V, Neely MD (2002) Carbonyl toxicology and Alzheimer's disease. Toxicol Appl Pharmacol 184: 187-197.

20. Ramassamy C, Krzywkowski $P$, Averill D, Lussier-Cacan S, Theroux L, et al. (2001) Impact of apoE deficiency on oxidative insults and antioxidant levels in the brain. Brain Res Mol Brain Res 86: 76-83.

21. Lovell MA, Markesbery WR (2007) Oxidative DNA damage in mild cognitive impairment and late-stage Alzheimer's disease. Nucleic Acids Res 35: 7497-7504.

22. Cini M, Moretti A (1995) Studies on lipid peroxidation and protein oxidation in the aging brain. Neurobiol Aging 16: 53-57.

23. Smith MA, Kutty RK, Richey PL, Yan SD, Stern D, et al. (1994) Heme oxygenase-1 is associated with the neurofibrillary pathology of Alzheimer's disease. Am J Pathol 145: 42-47.

24. Abd El Mohsen MM, Iravani MM, Spencer JP, Rose S, Fahim AT, et al. (2005) Age-associated changes in protein oxidation and proteasome activities in rat brain: modulation by antioxidants. Biochem Biophys Res Commun 336: 386-391.

25. Schippling S, Kontush A, Arlt S, Buhmann C, StÃ $\tilde{1}^{1 / 4}$ renburg HJ, et al. (2000) Increased lipoprotein oxidation in Alzheimer's disease. Free Radic Biol Med 28: $351-360$

26. Forster MJ, Dubey A, Dawson KM, Stutts WA, Lal H, et al. (1996) Age-related losses of cognitive function and motor skills in mice are associated with oxidative protein damage in the brain. Proc Natl Acad Sci U S A 93: 4765-4769.

27. Lindsay J, Laurin D, Verreault R, Hebert R, Helliwell B, et al. (2002) Risk factors for Alzheimer's disease: a prospective analysis from the Canadian Study of Health and Aging. Am J Epidemiol 156: 445-453.

28. Emard JF, Thouez JP, Gauvreau D (1995) Neurodegenerative diseases and risk factors: a literature review. Soc Sci Med 40: 847-858.

29. Brown RC, Lockwood AH, Sonawane BR (2005) Neurodegenerative diseases: an overview of environmental risk factors. Environ Health Perspect 113: 12501256.

30. Epis R, Gardoni F, Marcello E, Genazzani A, Canonico PL, et al. (2010) Searching for new animal models of Alzheimer's disease. Eur J Pharmacol 626: 57-63.

31. Alzheimer's Association, Thies W, Bleiler L (2011) 2011 Alzheimer's disease facts and figures. Alzheimers Dement 7: 208-244.

32. Meek PD, McKeithan K, Schumock GT (1998) Economic considerations in Alzheimer's disease. Pharmacotherapy 18: 68-73.

33. Wimo A, Prince M (2010) World Alzheimer Report 2010: The Global Economic Impact of Dementia Alzheimer's Disease International, London 1-56.

34. McCullagh CD, Craig D, Mcllroy SP, Passmore AP (2001) Risk factors for dementia. Adv Psychiatric Treatm 7: 24-31.

35. McDowell I (2001) Alzheimer's disease: insights from epidemiology. Aging (Milano) 13: 143-162.

36. Suh YH, Checler F (2002) Amyloid precursor protein, presenilins, and alphasynuclein: molecular pathogenesis and pharmacological applications in Alzheimer's disease. Pharmacol Rev 54: 469-525.

37. HÃ $1 / 4$ Il M, Berger M, Heneka M (2006) Disease-modifying therapies in Alzheimer's disease: how far have we come? Drugs 66: 2075-2093.

38. Golde TE, Schneider LS, Koo EH (2011) Anti-al ${ }^{2}$ therapeutics in Alzheimer's disease: the need for a paradigm shift. Neuron 69: 203-213.

39. Hampel H, Frank R, Broich K, Teipel SJ, Katz RG, et al. (2010) Biomarkers for
Alzheimer's disease: academic, industry and regulatory perspectives. Nat Rev Drug Discov 9: 560-574.

40. Frisoni GB, Fox NC, Jack CR Jr, Scheltens P, Thompson PM (2010) The clinical use of structural MRI in Alzheimer disease. Nat Rev Neurol 6: 67-77.

41. Putcha D, Brickhouse M, O'Keefe K, Sullivan C, Rentz D, et al. (2011) Hippocampal hyperactivation associated with cortical thinning in Alzheimer's disease signature regions in non-demented elderly adults. J Neurosci 31: 17680-17688.

42. Palop JJ, Chin J, Mucke L (2006) A network dysfunction perspective on neurodegenerative diseases. Nature 443: 768-773.

43. Verret L, Mann EO, Hang GB, Barth AM, Cobos I, Ho K et al. (2012) Key role of interneuronal impairments in Alzheimer's disease-related neural network and cognitive dysfunction. Cell doi. 10.1016/j.cell.2012.

44. Palop JJ, Mucke L (2010) Amyloid-beta-induced neuronal dysfunction in Alzheimer's disease: from synapses toward neural networks. Nat Neurosci 13 812-818.

45. Querfurth HW, LaFerla FM (2010) Alzheimer's disease. N Engl J Med 362 329-344.

46. Giannakopoulos P, Herrmann FR, Bussiere T, Bouras C, Kovari E, et al. (2003) Tangle and neuron numbers, but not amyloid load, predict cognitive status in Alzheimer's disease. Neurology 60: 1495-1500.

47. Morris M, Maeda S, Vossel K, Mucke L (2011) The many faces of tau. Neuron 70: $410-426$

48. Roberson ED, Mucke $L$ (2006) 100 years and counting: prospects for defeating Alzheimer's disease. Science 314: 781-784.

49. Jacobsen JS, Reinhart $P$, Pangalos MN (2005) Current concepts in therapeutic strategies targeting cognitive decline and disease modification in Alzheimer's disease. NeuroRx 2: 612-626.

50. David BH, Peter B, Anne C, Barry C, Carole C, et al. (2007) Management of Mild to Moderate Alzheimer disease and Dementia. Alzheimer's \& Dementia 3: 355-384.

51. Davis KL, Thal LJ, Gamzu ER, Davis CS, Woolson RF, et al. (1992) A doubleblind, placebo-controlled multicenter study of tacrine for Alzheimer's disease. The Tacrine Collaborative Study Group. N Engl J Med 327: 1253-1259.

52. Knapp MJ, Knopman DS, Solomon PR, Pendlebury WW, Davis CS, et al (1994) A 30-week randomized controlled trial of high-dose tacrine in patients with Alzheimer's disease. The Tacrine Study Group. JAMA 271: 985-991.

53. Rosler M, Anand R, Cicin-Sain A, Gauthier S, Agid Y, et al. (1999) Efficacy and safety of rivastigmine in patients with Alzheimer's disease: international randomised controlled trial. BMJ 318: 633-638

54. Tariot PN, Solomon PR, Morris JC, Kershaw P, Lilienfeld S, et al. (2000) A 5 -month, randomized, placebo-controlled trial of galantamine in AD. The Galantamine USA-10 Study Group. Neurology 54: 2269-2276.

55. van Dyck CH, Newhouse P, Falk WE, Mattes JA (2000) Extended-release physostigmine in Alzheimer disease: a multicenter, double-blind, 12-week study with dose enrichment. Physostigmine Study Group. Arch Gen Psychiatry 57: 157-164.

56. Richardson RJ (1995) Assessment of the neurotoxic potential of chlorpyrifos relative to other organophosphorus compounds: a critical review of the literature. J Toxicol Environ Health 44: 135-165.

57. Cummings JL (2004) Alzheimer's disease. N Engl J Med 351: 56-67.

58. Greenamyre JT, Maragos WF, Albin RL, Penney JB, Young AB (1988) Glutamate transmission and toxicity in Alzheimer's disease. Prog Neuropsychopharmacol Biol Psychiatry 12: 421-430.

59. Wenk GL, Danysz W, Mobley SL (1995) MK-80, memantine and amantadine show neuroprotective activity in the nucleus basalis magnocellularis. Eur J Pharmacol 293: 267-270.

60. Reisberg B, Stoeffler A, Ferris S (2002) A placebo-controlled study of memantine in advanced Alzheimer's disease. Am J Geriatr Psychiatry 10: 1-122.

61. Helmuth $L$ (2002) New therapies. New Alzheimer's treatments that may ease the mind. Science 297: 1260-1262.

62. Chen W, Song X, Beyea S, D'Arcy R, Zhang Y, et al. (2011) Advances in perfusion magnetic resonance imaging in Alzheimer's disease. Alzheimers Dement 7: 185-196. 
63. Rezai-Zadeh K, Shytle O, Sun1 N, Mori T, Hou H, Jeanniton D et al. (2005) Green tea epigallocatechin-3-gallate (EGCG) modulates amyloid precursor protein cleavage and reduces cerebral amyloidosis in Alzheimer transgenic mice. J Neurosci 25: 8807-8814.

64. Lim GP, Calon F, Morihara T, Yang F, Teter B, et al. (2005) A diet enriched with the omega-3 fatty acid docosahexaenoic acid reduces amyloid burden in an aged Alzheimer mouse model. J Neurosci 25: 3032-3040.

65. Cherny RA, Atwood CS, Xilinas ME, Gray DN, Jones WD, et al. (2001) Treatment with a copper-zinc chelator markedly and rapidly inhibits betaamyloid accumulation in Alzheimer's disease transgenic mice. Neuron 30: 665676.

66. Schenk D, Barbour R, Dunn W, Gordon G, Grajeda H, et al. (1999) Immunization with amyloid-beta attenuates Alzheimer-disease-like pathology in the PDAPP mouse. Nature 400: 173-177.

67. Rockwood K, Kirkland S, Hogan DB, MacKnight C, Merry H, et al. (2002) Use of lipid-lowering agents, indication bias, and the risk of dementia in communitydwelling elderly people. Arch Neurol 59: 223-227.

68. Bard F, Cannon C, Barbour R, Burke RL, Games D, et al. (2000) Peripherally administered antibodies against amyloid beta-peptide enter the central nervous system and reduce pathology in a mouse model of Alzheimer disease. Nat Med 6: 916-919.

69. Arendash GW, Gordon MN, Diamond DM, Austin LA, Hatcher JM, et al. (2001) Behavioral assessment of Alzheimer's transgenic mice following long-term Abeta vaccination: task specificity and correlations between Abeta deposition and spatial memory. DNA Cell Biol 20: 737-744.

70. Janus C, Pearson J, McLaurin J, Mathews PM, Jiang Y, et al. (2000) A beta peptide immunization reduces behavioural impairment and plaques in a model of Alzheimer's disease. Nature 408: 979-982.

71. Hawkes CA, McLaurin J (2007) Immunotherapy as treatment for Alzheimer's disease. Expert Rev Neurother 7: 1535-1548.

72. Kawas C, Resnick S, Morrison A, Brookmeyer R, Corrada M, et al. (1997) A prospective study of estrogen replacement therapy and the risk of developing Alzheimer's disease: the Baltimore Longitudinal Study of Aging. Neurology 48: 1517-1521.

73. Baldereschi M, Di Carlo A, Lepore V, Bracco L, Maggi S, et al. (1998) Estrogenreplacement therapy and Alzheimer's disease in the Italian Longitudinal Study on Aging. Neurology 50: 996-1002.

74. Aisen PS, Davis KL (1994) Inflammatory mechanisms in Alzheimer's disease: implications for therapy. Am J Psychiatry 151: 1105-1113.

75. Nathan L, Chaudhuri G (1998) Antioxidant and prooxidant actions of estrogens: potential physiological and clinical implications. Semin Reprod Endocrinol 16: 309-314.

76. Bezprozvanny I (2010) The rise and fall of Dimebon. Drug News Perspect 23: 518-523.

77. Galimberti D, Scarpini E (2011) Inflammation and oxidative damage in Alzheimer's disease: friend or foe? Front Biosci (Schol Ed) 3: 252-266.

78. Perry VH, Nicoll JA, Holmes C (2010) Microglia in neurodegenerative disease. Nat Rev Neurol 6: 193-201.

79. Morris MC, Beckett LA, Scherr PA, Hebert LE, Bennett DA, et al. (1998) Vitamin $\mathrm{E}$ and vitamin $\mathrm{C}$ supplement use and risk of incident Alzheimer disease. Alzheimer Dis Assoc Disord 12: 121-126.

80. Lee HP, Zhu X, Casadesus G, Castellani RJ, Nunomura A, et al. (2010) Antioxidant approaches for the treatment of Alzheimer's disease. Expert Rev Neurother 10: 1201-1208.

81. Cole GM, Frautschy SA (2010) Mechanisms of action of non-steroidal antiinflammatory drugs for the prevention of Alzheimer's disease. CNS Neurol Disord Drug Targets 9: 140-148.

82. Sano M, Ernesto C, Thomas RG, Klauber MR, Schafer K, et al. (1997) A controlled trial of selegiline, alpha-tocopherol, or both as treatment for Alzheimer's disease. The Alzheimer's Disease Cooperative Study. N Engl J Med 336: 1216-1222

83. Jack CR Jr, Albert MS, Knopman DS, McKhann GM, Sperling RA, et al. (2011) Introduction to the recommendations from the National Institute on AgingAlzheimer's Association workgroups on diagnostic guidelines for Alzheimer's disease. Alzheimers Dement 7: 257-262.

84. Head E (2007) Combining an antioxidant-fortified diet with behavioral enrichment leads to cognitive improvement and reduced brain pathology in aging canines: strategies for healthy aging. Ann N Y Acad Sci 1114: 398-406.

85. Martin LJ, Pardo CA, Cork LC, Price DL (1994) Synaptic pathology and glial responses to neuronal injury precede the formation of senile plaques and amyloid deposits in the aging cerebral cortex. Am J Pathol 145: 1358-1381.

86. Schultz C, Hubbard GB, RÃ $1 / 4 \mathrm{~b}$ U, Braak E, Braak H (2000) Age-related progression of tau pathology in brains of baboons. Neurobiol Aging 21: 905912.

87. Nicoll JA, Barton E, Boche D, Neal JW, Ferrer I, et al. (2006) Abeta species removal after abeta42 immunization. J Neuropathol Exp Neurol 65: 1040-1048.

88. Schenk D, Hagen M, Seubert P (2004) Current progress in beta-amyloid immunotherapy. Curr Opin Immunol 16: 599-606.

89. Henley DB, May PC, Dean RA, Siemers ER (2009) Development of semagacestat (LY450139), a functional gamma-secretase inhibitor, for the treatment of Alzheimer's disease. Expert Opin Pharmacother 10: 1657-1664.

90. Bateman RJ, Siemers ER, Mawuenyega KG, Wen G, Browning KR, et al (2009) A gamma-secretase inhibitor decreases amyloid-beta production in the central nervous system. Ann Neurol 66: 48-54

91. Shineman DW, Basi GS, Bizon JL, Colton CA, Greenberg BD, et al. (2011) Accelerating drug discovery for Alzheimer's disease: best practices for preclinical animal studies. Alzheimers Res Ther 3: 28.

92. Luo F, Rustay NR, Seifert T, Roesner B, Hradil V, et al. (2010) Magnetic resonance imaging detection and time course of cerebral microhemorrhages during passive immunotherapy in living amyloid precursor protein transgenic mice. J Pharmacol Exp Ther 335: 580-588.

93. Luo F, Rustay NR, Ebert U, Hradil VP, Cole TB, et al. (2012) Characterization of 7- and 19-month-old Tg2576 mice using multimodal in vivo imaging: limitations as a translatable model of Alzheimer's disease. Neurobiol Aging 33: 933-944.

94. Portelius E, Zhang B, Gustavsson MK, Brinkmalm G, Westman-Brinkmalm A et al. (2009) Effects of gamma-secretase inhibition on the amyloid beta isoform pattern in a mouse model of Alzheimer's disease. Neurodegener Dis 6: 258-262.

95. Norfray JF, Provenzale JM (2004) Alzheimer's disease: neuropathologic findings and recent advances in imaging. AJR Am J Roentgenol 182: 3-13.

96. Gotz J, Ittner LM (2008) Animal models of Alzheimer's disease and frontotemporal dementia. Nat Rev Neurosci 9: 532-544.

97. Klunk WE, Lopresti BJ, Ikonomovic MD, Lefterov IM, Koldamova RP, et al. (2005) Binding of the positron emission tomography tracer Pittsburgh compound-B reflects the amount of amyloid-beta in Alzheimer's disease brain but not in transgenic mouse brain. J Neurosci 25: 10598-10606.

98. Klunk WE, Engler H, Nordberg A, Wang Y, Blomqvist G, et al. (2004) Imaging brain amyloid in Alzheimer's disease with Pittsburgh Compound-B. Ann Neurol 55: 306-319.

99. Westerman MA, Cooper-Blacketer D, Mariash A, Kotilinek L, Kawarabayashi T, et al. (2002) The relationship between Abeta and memory in the Tg2576 mouse model of Alzheimer's disease. J Neurosci 22: 1858-1867.

100. Van Dam D, De Deyn PP (2006) Drug discovery in dementia: the role of rodent models. Nat Rev Drug Discov 5: 956-970.

101. Gotz J, Streffer JR, David D, Schild A, Hoerndli F, et al. (2004) Transgenic animal models of Alzheimer's disease and related disorders: histopathology, behavior and therapy. Mol Psychiatry 9: 664-683.

102.Buxbaum JD, Christensen JL, Ruefli AA, Greengard P, Loring JF (1993) Expression of APP in brains of transgenic mice containing the entire human APP gene. Biochem Biophys Res Commun 197: 639-645.

103. Lamb BT, Sisodia SS, Lawler AM, Slunt HH, Kitt CA, et al. (1993) Introduction and expression of the 400 kilobase amyloid precursor protein gene in transgenic mice [corrected]. Nat Genet 5: 22-30.

104.Moran PM, Higgins LS, Cordell B, Moser PC (1995) Age-related learning deficits in transgenic mice expressing the 751-amino acid isoform of human beta-amyloid precursor protein. Proc Natl Acad Sci U S A 92: 5341-5345.

105. Quon D, Wang Y, Catalano R, Scardina JM, Murakami K, et al. (1991) Formation of beta-amyloid protein deposits in brains of transgenic mice. Nature 352: 239-241.

106. Yamaguchi F, Richards SJ, Beyreuther K, Salbaum M, Carlson GA, et al. (1991) Transgenic mice for the amyloid precursor protein 695 isoform have impaired spatial memory. Neuroreport 2: 781-784. 
107. Wirak DO, Bayney R, Ramabhadran TV, Fracasso RP, Hart JT, et al. (1991) Deposits of amyloid beta protein in the central nervous system of transgenic mice. Science 253: 323-325.

108. Sandhu FA, Salim M, Zain SB (1991) Expression of the human beta-amyloid protein of Alzheimer's disease specifically in the brains of transgenic mice. $J$ Biol Chem 266: 21331-21334.

109. Santacruz K, Lewis J, Spires T, Paulson J, Kotilinek L, et al. (2005) Tau suppression in a neurodegenerative mouse model improves memory function. Science 309: 476-481.

110. Ohno M, Sametsky EA, Younkin LH, Oakley H, Younkin SG, et al. (2004) BACE1 deficiency rescues memory deficits and cholinergic dysfunction in a mouse model of Alzheimer's disease. Neuron 41: 27-33.

111. Saura CA, Choi SY, Beglopoulos V, Malkani S, Zhang D, Shankaranarayana BS, et al. (2004) Loss of presenilin function causes impairments of memory and synaptic plasticity followed by age-dependent neurodegeneration. Neuron 42: 23-36.

112. Luo Y, Bolon B, Kahn S, Bennett BD, Babu-Khan S, et al. (2001) Mice deficient in BACE, the Alzheimer's beta-secretase, have normal phenotype and abolished beta-amyloid generation. Nat Neurosci 4: 231-232.

113. Wahrle SE, Jiang H, Parsadanian M, Hartman RE, Bales KR, et al. (2005) Deletion of Abca1 increases Abeta deposition in the PDAPP transgenic mouse model of Alzheimer disease. J Biol Chem 280: 43236-43242.

114. Koldamova R, Staufenbiel M, Lefterov I (2005) Lack of ABCA1 considerably decreases brain ApoE level and increases amyloid deposition in APP23 mice. J Biol Chem 280: 43224-43235.

115. Hirsch-Reinshagen V, Maia LF, Burgess BL, Blain JF, Naus KE, et al. (2005) The absence of ABCA1 decreases soluble ApoE levels but does not diminish amyloid deposition in two murine models of Alzheimer disease. J Biol Chem 280: 43243-43256.

116. Stokin GB, Lillo C, Falzone TL, Brusch RG, Rockenstein E, et al. (2005) Axonopathy and transport deficits early in the pathogenesis of Alzheimer's disease. Science 307: 1282-1288.

117. Driscoll M, Gerstbrein B (2003) Dying for a cause: invertebrate genetics takes on human neurodegeneration. Nat Rev Genet 4: 181-194.

118. Jackson GR, Wiedau-Pazos M, Sang TK, Wagle N, Brown CA, et al. (2002) Human wild-type tau interacts with wingless pathway components and produces neurofibrillary pathology in Drosophila. Neuron 34: 509-519.

119. Kraemer BC, Zhang B, Leverenz JB, Thomas JH, Trojanowski JQ, et al. (2003) Neurodegeneration and defective neurotransmission in a Caenorhabditis elegans model of tauopathy. Proc Natl Acad Sci U S A 100: 9980-9985.

120. Miyasaka T, Ding Z, Gengyo-Ando K, Oue M, Yamaguchi H, et al. (2005) Progressive neurodegeneration in $\mathrm{C}$. elegans model of tauopathy. Neurobiol Dis 20: $372-383$.

121. David DC, Hoerndli F, Gotz J (2005) Functional Genomics meets neurodegenerative disorders Part I: transcriptomic and proteomic technology. Prog Neurobiol 76: 153-168.

122. Koh MT, Haberman RP, Foti S, McCown TJ, Gallagher M (2010) Treatment strategies targeting excess hippocampal activity benefit aged rats with cognitive impairment. Neuropsychopharmacology 35: 1016-1025.
123. Cohen E, Paulsson JF, Blinder P, Burstyn-Cohen T, Du D, et al. (2009) Reduced IGF-1 signaling delays age-associated proteotoxicity in mice. Cell 139: 1157-1169.

124.Gan L, Mucke L (2008) Paths of convergence: sirtuins in aging and neurodegeneration. Neuron 58: 10-14.

125. Harris H, Rubinsztein DC (2011) Control of autophagy as a therapy for neurodegenerative disease. Nat Rev Neurol 8: 108-117.

126. Vassar R, Bennett BD, Babu-Khan S, Kahn S, Mendiaz EA, et al. (1999) Beta-secretase cleavage of Alzheimer's amyloid precursor protein by the transmembrane aspartic protease BACE. Science 286: 735-741.

127. Kobayashi D, Zeller M, Cole T, Buttini M, McConlogue L, et al. (2008) BACE1 gene deletion: impact on behavioral function in a model of Alzheimer's disease. Neurobiol Aging 29: 861-873.

128. Braak H, Braak E (1991) Neuropathological stageing of Alzheimer-related changes. Acta Neuropathol 82: 239-259.

129. Bullock R (2002) New drugs for Alzheimer's disease and other dementias. $\mathrm{Br}$ J Psychiatry 180: 135-139.

130. Komater VA, Browman KE, Curzon P, Hancock AA, Decker MW, et al. (2003) $\mathrm{H} 3$ receptor blockade by thioperamide enhances cognition in rats without inducing locomotor sensitization. Psychopharmacology (Berl) 167: 363-372.

131.Danysz W (2002) CX-516 Cortex pharmaceuticals. Curr Opin Investig Drugs 3: $1081-1088$.

132. Koch HJ, Szecsey A, Haen E (2004) NMDA-antagonism (memantine): an alternative pharmacological therapeutic principle in Alzheimer's and vascular dementia. Curr Pharm Des 10: 253-259.

133. King MV, Sleight AJ, Woolley ML, Topham IA, Marsden CA, et al. (2004) 5-HT6 receptor antagonists reverse delay-dependent deficits in novel object discrimination by enhancing consolidation--an effect sensitive to NMDA receptor antagonism. Neuropharmacology 47: 195-204.

134. Schechter LE, Smith D, Rosenzweig-Lipson S, Sukoff S, Dawson L, et al (2005) Lecozotan (Sra-333): a selective serotonin1a receptor antagonist that enhances the stimulated release of glutamate and acetylcholine in the hippocampus and possesses cognitive-enhancing properties. J Pharmacol Exp Ther 314: 1274-89.

135. Winblad B, Poritis N (1999) Memantine in severe dementia: results of the 9M-Best Study (Benefit and efficacy in severely demented patients during treatment with memantine). Int J Geriatr Psychiatry 14: 135-146.

136. Winblad B, Jelic $V(2003)$ Treating the full spectrum of dementia with memantine. Int J Geriatr Psychiatry 18: S41-46.

137. Winblad B, Mobius HJ, Stoffler A (2002) Glutamate receptors as a target for Alzheimer's disease--are clinical results supporting the hope? J Neural Transm Suppl : 217-225.

138. Willem M, Dewachter I, Smyth N, Dooren V, Borghgraef P, et al. (2004) ß-site amyloid precursor protein cleaving enzyme 1 increases amyloid deposition in brain parenchyma but reduces cerebrovascular amyloid angiopathy in aging BACE x APP[V717I] double-transgenic mice. Am J Pathol 165: 1621-1631.

139. Mc Conlogue L, Buttini M, Anderson JP, Brigham EF, Chen KS, et al. (2007) Partial reduction of BACE1 has dramatic effects on Alzheimer plaque and synaptic pathology in APP Transgenic Mice. J Biol Chem 282: 26326-26334. 